\title{
PENGARUH MOTIVASI BELAJAR EKONOMI DAN LINGKUNGAN TEMAN SEBAYA TERHADAP HASIL BELAJAR MATA PELAJARAN EKONOMI SISWA KELAS X
}

\author{
Neni Afriul Karimah \& Sunanik \\ STKIP PGRI Tulungagung, Indonesia \\ neninefrika88@gmail.com,sunanik@stkippgritulungagung.ac.id
}

\begin{abstract}
Abstrak: Tujuan dari penelitian ini adalah : (1) mengetahui pengaruh motivasi belajar ekonomi terhadap hasil belajar mata pelajaran ekonomi siswa kelas X SMAN 1 Kampak tahun pelajaran 2017/2018, (2) mengetahui pengaruh lingkungan teman sebaya terhadap hasil belajar mata pelajaran ekonomi siswa kelas X SMAN 1 Kampak tahun pelajaran 2017/2018, (3) mengetahui pengaruh motivasi belajar ekonomi dan lingkungan teman sebaya terhadap hasil belajar mata pelajaran ekonomi siswa kelas X SMAN 1 Kampak tahun ajaran 2017/2018. Populasi penelitian ini adalah siswa kelas X SMA Negeri 1 Kampak yang berjumlah 185 siswa. Sampel diambil $40 \%$ dari populasi yaitu sebanyak 74 siswa. Teknik pengambilan sampling dilakukan dengan Proporsional random sampling. Dengan demikian penelitian ini disimpulkan "ada pengaruh signifikan antara motivasi belajar ekonomi dan lingkungan teman sebaya terhadap hasil belajar mata pelajaran ekonomi". Hasil penelitian ini dapat digunakan untuk masukan dalam meningkatkan hasil belajar mata pelajaran ekonomi.
\end{abstract}

Kata kunci: Motivasi Belajar, Lingkungan Teman Sebaya Dan Hasil Belajar

\section{THE INFLUENCE OF ECONOMIC LEARNING MOTIVATION AND PEER ENVIRONMENT TOWARD STUDENTS' LEARNING RESULTS IN ECONOMIC SUBJECT IN GRADE $X$}

\begin{abstract}
This research aims to (1) identify whether or not the influence of Economic learning motivation toward learning results in Economic subject in grade X students in SMAN 1 Kampak 2017/2018 exists, (2) identify whether or not the influence of peer environment toward learning results in Economic subject in grade X students in SMAN 1 Kampak 2017/2018 exists, (3) identify whether or not Economic learning motivation and peer environment toward learning results in Economic subject in grade X students in SMAN 1 Kampak 2017/2018 exist. The population of this research is all grade $X$ students in SMAN 1 Kampak. There are 185 students that become the population of this research. The sample of this research is $40 \%$ of the population. There are 74 students that become the sample of this research. Proportional random sampling is used as sampling technique for this research.Therefore, it can be concluded that there is a significant influence between Economic learning motivation and peer environment toward students' learning results. The results of this research can then be used as a consideration to advance the students' learning results in Economic subject.
\end{abstract}

Keywords: Learning Motivation, Peer Environment, Learning Results

\section{PENDAHULUAN}

Di era globalisasi saat ini pendidikan sangat penting dan sangat erat kaitannya dengan kehidupan di masyarakat. Tanpa adanya pendidikan yang cukup maka seseorang tidak memiliki wawasan yang luas, maka dari itu pendidikan sangat penting didapatkan oleh seseorang untuk bisa menjamin suatu kehidupannya di masa depan. Dalam UUD 1945 amandemen pasal 31 ayat 1 dan 2 telah disebutkan bahwa setiap warga negara berhak mendapatkan pendidikan dan setiap warga negara wajib mengikuti pendidikan dasar dan pemerintah wajib membiayainya, hal itu menjelaskan bahwa pendidikan sangat penting untuk semua orang. Menurut Syah (2010:10) Pendidikan diartikan sebagai cara bertingkah laku untuk mendapatkan pengetahuan, pemahaman yang diperoleh seseorang dengan metode-metode tertentu yang disesuaikan dengan kebutuhan. 
Pemberian mata pelajaran di sekolah disesuaikan dengan pembaruan pendidikan dan teknologi, yang diharapkan dapat menghasilkan siswa dengan prestasi yang baik. Prestasi yang baik didukung dengan hasil belajar yang mampu mencapai Kriteria Ketuntasan Minimal (KKM).Sehingga dengan hasil belajar yang baik diharapkan siswa mampu menentukan jenjang pendidikan selanjutnya atau mencari lapangan pekerjaan dengan kemampuannya.

Salah satu jalur pendidikan yang ada adalah pendidikan formal. SMAN 1 Kampak, Trenggalek merupakan salah satu lembaga pendidikan formal yang menyelenggarakan pendidikan bagi siswa. Pada program studi Ilmu Pengetahuan Sosial (IPS), terdapat beberapa mata pelajaran yang wajib untuk dipelajari. Di antara mata pelajaran wajib tersebut, ekonomi merupakan salah satu mata pelajaran yang wajib ditempuh oleh siswa SMA pada kelas X IPA dan IPS. Setelah siswa belajar mata pelajaran ekonomi, guru akan melakukan evaluasi hasil belajar mata pelajaran ekonomi pada peserta didik seperti Ulangan Harian (UH), Ujian Tengah Semester (UTS) dan Ujian Akhir Semester (UAS).

Berdasarkan hasil wawancara dengan guru mata pelajaran ekonomi di SMA Negeri 1 Kampak, mengatakan bahwa masih banyak siswa yang hasil belajarnya mata pelajaran ekonomi masih banyak nilai yang kurang, hal tersebut terlihat pada nilai ulangan harian, maupun ulangan semester siswa kelas X tahun ajaran 2017/2018 masih di bawah Kriteria Ketuntasan Minimal (KKM) sedangkan nilai KKM sekolah yaitu 70. Belum maksimalnya hasil belajar mata pelajaran ekonomi salah satunya dikarenakan belum maksimalnya motivasi belajar ekonomi pada diri siswa. Siswa cenderung tidak memperhatikan, tidak bertanya ketika mengalami kesulitan belajar dan lain sebagainya.

Perbedaan antara hasil belajar dengan prestasi belajar yaitu : Menurut (Mutmainah, 2014:22) hasil belajar adalah hasil kemampuan seseorang pada bidang tertentu dan dapat diukur langsung menggunakan tes dalam mencapai tingkat kedewasaan. Menurut (Dewi, 2015:18) hasil belajar ekonomi merupakan hasil belajar mata pelajaran ekonomi dalam rangka perubahan perilaku, yang diwujudkan dalam bentuk sikap, pengetahuan, penguasaan kemampuan maupun keterampilan yang dapat memberikan perubahan perilaku yang dapat dipengaruhi berbagai faktor, kepercayaan diri, cara belajar maupun kecerdasan emosional. Menurut (Yuli, 2016:17) Hasil belajar merupakan kemampuan yang dapat memberikan perubahan arah yang lebih baik ke depannya setelah individu melakukan berlangsungnya proses pembelajaran.

Menurut (Wekke, 2016:82-83) prestasi mengandung arti adalah "manifestasi dari kemampuan potensial peserta didik yang diasuh, ini berlangsung karena adanya usaha sadar dari proses belajar yang disengaja. Maka, prestasi belajar merupakan perubahan perilaku sebagai hasil usaha berdasarkan interaksi dengan lingkungan dan juga terdapat di dalamnya usaha yang digerakkan oleh individu itu sendiri. Prestasi bukanlah diukur dengan satu-satunya bentuk yaitu dengan juara". Menurut Purwato (Habsari, 2005:75) prestasi belajar adalah "hasil-hasil belajar yang telah diberikan guru kepada murid-murid atau dosen kepada mahasiswanya dalam jangka tertentu". Menurut Ahmad (Habsari: 2005:75) prestasi belajar adalah "hasil yang dicapai dalam suatu usaha belajar untuk mengadakan perubahan atau mencapai tujuan".

Sehingga dari teori para ahli di atas dapat disimpulkan bahwa hasil belajar merupakan hasil kemampuan dari seseorang di bidang tertentu yang diwujudkan dalam bentuk penguasaan kemampuan, sikap, pengetahuan maupun keterampilan yang di ukur menggunakan tes. sedangkan prestasi belajar disimpulkan bahwa hasil-hasil yang telah diperoleh siswa dari berbagai bidang yang telah dicapai dalam suatu usaha untuk mencapai sebuah tujuan dalam bentuk juara.

Hasil belajar mata pelajaran ekonomi merupakan suatu hal yang penting bagi siswa. Keberhasilan dalam pembelajaran dapat dilihat outputnya yaitu hasil belajar mata pelajaran 
ekonomi. Hasil belajar merupakan suatu nilai dari suatu pengujian atau tes yang ditandai dengan nilai atau simbol dari penguasaan pengetahuan, keterampilan, dan sikap yang didapatkan siswa dalam mengikuti proses belajar mengajar (Rahayu, 2017:2). Hasil belajar mata pelajaran ekonomi dapat dilihat dari hasil tes ulangan semester genap. Karena hasil belajar merupakan tolak ukur yang digunakan untuk menentukan tingkat keberhasilan siswa, sejauh mana siswa memahami dan menguasai suatu materi pelajaran ekonomi. Kemungkinan kurangnya hasil belajar mata pelajaran ekonomi siswa kelas X SMAN 1 Kampak dipengaruhi oleh motivasi belajar dan lingkungan teman sebaya.

Hasil belajar dapat dipengaruhi dari faktor internal. "Faktor internal (faktor yang berasal dari dalam diri) berupa faktor jasmaniah yaitu kondisi fisik seseorang, faktor psikologis yang dapat mempengaruhi belajar di antaranya intelegensi, perhatian, minat, bakat, motif, kematangan serta kesiapan" (Julianty, 2014:2). Salah satu faktor internal yaitu motivasi belajar. Motivasi adalah sesuatu yang dibutuhkan untuk melakukan aktivitas. Motivasi belajar yaitu segala sesuatu yang dapat memotivasi peserta didik atau individu untuk belajar. Peserta didik tidak akan mencapai keberhasilan dalam hasil belajarnya tanpa adanya motivasi belajar Sani (2013:49). Menurut (Djaali, 2009:101) Motivasi adalah sesuatu yang terdapat dalam diri seseorang yang berupa kondisi fisiologis dan psikologis yang dapat mendorongnya untuk melakukan aktivitas tertentu untuk mendapatkan suatu tujuan (kebutuhan).Dibutuhkan peran motivasi yang sangat besar dalam mempelajari tingkah laku seseorang. Menurut Wisnubroto Hendro Juwono motivasi menyebabkan timbulnya berbagai tingkah laku, yang sangat di perlukan dalam (stimulus yang mempertahankan tingkah laku yang dikehendaki) dalam proses belajar (Djaali, 2009:104). Menurut Furqon, K.A (2016:2) "dalam proses belajar mengajar motivasi sangat besar peranannya terhadap hasil belajar. karena dengan adanya motivasi dapat menumbuhkan minat belajar siswa. Bagi siswa yang memiliki motivasi yang kuat akan mempunyai keinginan untuk melaksanakan kegiatan belajar mengajar".

Selain faktor internal terdapat pula faktor yang dapat mempengaruhi hasil belajar siswa yaitu faktor eksternal Julianty (2014:2) "Faktor eksternal yang berupa faktor sekolah maupun faktor masyarakat salah satunya yang dapat mempengaruhi keberhasilan belajar siswa adalah relasi siswa, siswa di sekolah, teman bergaul pada masyarakat dan teman sebaya. Dalam dunia pendidikan SMA tidak lepas dari dunia remaja, karena pendidikan tingkat SMA terjadi pada masa remaja". Menurut Dewi (2015:26) lingkungan teman sebaya merupakan orang-orang yang mempunyai kesamaan usia dan status dalam melakukan interaksi di sebuah lingkungan yang cukup teratur. Menurut (Maheni, 2017) Teman sebaya biasanya memberikan dorongan-dorongan sekaligus suasana membangun apabila berada di dalam kelas atau di luar kelas, memiliki usia dan tingkat kematangan yang relatif sama, sehingga terjalin komunikasi yang dialogis. Dan diperjelas oleh Julianty (2014: 2-3) Teman sebaya dapat memberikan dampak positif maupun negatif. Rahayu (2017: 4) menyatakan bahwa "pengaruh lingkungan teman sebaya dapat terjadi di dalam kelas, hal tersebut biasanya disebabkan oleh teman yang suka mengajak ngobrol, siswa seringkali sulit untuk focus dalam belajar. Sehingga berdampak pada pemahaman materi yang telah diajarkan guru. Terkadang jika teman nya mengerjakan tugas maka siswa lain juga akan mengikuti temannya yang mengerjakan tugas, dan begitu pun sebaliknya. Oleh karena itu belum maksimalnya hasil belajar siswa dipengaruhi oleh faktor lingkungan teman sebaya". Teman sebaya yang baik dapat memberikan pengaruh yang positif, di mana teman sebaya dapat memberikan dorongan untuk giat belajar agar mencapai hasil belajar yang baik dan mampu bersaing secara sehat dalam kegiatan belajar. Di mana apabila siswa berteman dengan siswa yang rajin maka siswa tersebut juga akan menjadi rajin dalam mengerjakan tugas. Akan tetapi jika siswa berteman dengan siswa yang kurang rajin dalam mengerjakan tugas, maka siswa juga akan mengikuti temannya yaitu juga malas dalam mengerjakan tugasnya. 
Penelitian yang dilakukan oleh Damayanti (2015) yang berjudul "pengaruh motivasi belajar dan lingkungan keluarga terhadap hasil belajar matematika siswa kelas VIII_A, bahwa terdapat pengaruh yang signifikan antara motivasi belajar terhadap hasil belajar. Penelitian yang dilakukan oleh Mut'ah Mutmainah (2014), yang berjudul Pengaruh Motivasi Belajar Terhadap Hasil Belajar Siswa Pada Bidang Studi Sejarah Kebudayaan Islam (SKI) di MTS'N 19 Jakarta. Terdapat pengaruh yang signifikan antara motivasi belajar terhadap hasil belajar. Penelitian yang dilakukan oleh menurut Erma Yuli (2016) dengan judul "Pengaruh Motivasi Belajar Dan Minat Baca Terhadap Hasil Belajar Ekonomi Siswa Kelas XI IPS Semester Ganjil SMA Negeri 15 Bandar Lampung Tahun Ajaran 2015/2015. Yang menyatakan bahwa terdapat pengaruh yang positif dan signifikan antara motivasi belajar terhadap hasil belajar ekonomi siswa kelas XI IPS semester ganjil SMA Negeri 15 Bandar Lampung Tahun Ajaran 2015/2016. Penelitian yang dilakukan oleh Retno Singga Dewi (2015) yang berjudul "Pengaruh Disiplin Belajar Dan Lingkungan Teman Sebaya Terhadap Hasil Belajar Siswa Pada Mata Pelajaran Ekonomi Kelas XI IPS Di SMA Negeri 14 Semarang". Yang menunjukkan dari hasil penelitiannya menunjukkan bahwa terdapat pengaruh secara parsial lingkungan teman sebaya terhadap hasil belajar siswa pada mata pelajaran ekonomi kelas X1 IPS di SMA Negeri 14 Semarang tahun ajaran 2014/2015 sebesar 18,8\%. Penelitian yang dilakukan oleh Rahayu (2017, hal. 85-86) Terdapat pengaruh positif dan signifikan lingkungan teman sebaya dan motivasi belajar secara bersama-sama terhadap hasil belajar ekonomi siswa kelas X IIS SMA Negeri 1 Sewon Tahun Ajaran 2016/2017. Motivasi Belajar dan Lingkungan Teman Sebaya merupakan faktor internal dan eksternal dari Hasil Belajar Mata Pelajaran Ekonomi, sehingga penelitian ini diharapkan bahwa Motivasi Belajar Mata Pelajaran Ekonomi dan Lingkungan Teman Sebaya dapat meningkatkan Hasil Belajar Mata Pelajaran Ekonomi Siswa.

Sesuai dengan permasalahan di atas, maka tujuan penelitian ini untuk mengetahui pengaruh motivasi belajar ekonomi dan lingkungan teman sebaya terhadap hasil belajar mata pelajaran ekonomi siswa kelas X SMAN 1 Kampak tahun pelajaran 2017/2018 baik secara parsial maupun secara simultan.

\section{METODE}

Penelitian ini dilakukan dengan menggunakan metode penelitian kuantitatif korelasional, variabel bebas dalam penelitian ini yaitu motivasi belajar ekonomi dan lingkungan teman sebaya. Sedangkan variabel terikatnya hasil belajar mata pelajaran ekonomi. Metode pengumpulan data menggunakan angket dan tes. Menurut Sugiyono (2011:80), "populasi adalah wilayah generalisasi yang terdiri atas: objek/subjek yang mempunyai kualitas dan karakteristik tertentu yang ditetapkan oleh peneliti untuk dipelajari dan kemudian ditarik kesimpulannya". Dalam penelitian ini yang menjadi populasi adalah keseluruhan siswa kelas X SMAN 1 Kampak yang berjumlah 185 siswa.

Menurut Arikunto (2002:12) pengambilan sampel apabila subjeknya kurang dari 100, lebih baik diambil semua sehingga penelitiannya merupakan penelitian populasi. Tetapi, jika jumlah subjeknya besar, dapat diambil antara $10-15 \%$ atau $20-25 \%$ atau lebih, tergantung setidak-tidaknya dari:

1. Kemampuan peneliti dilihat dari waktu, tenaga, dan dana.

2. Sempit luasnya wilayah pengamatan dari setiap subjek.

3. Besar kecilnya risiko yang ditanggung oleh peneliti.

Sehingga sampel dalam penelitian ini diambil sebesar $40 \%$ dari jumlah populasi, dan teknik sampling yang digunakan yaitu proporsional random sampling. Menurut Riduwan (2010:242) menyatakan "Proportional Random Sampling ialah pengambilan sampel dari anggota populasi secara 
acak dan berstrata secara proporsional, dilakukan sampling ini apabila anggota populasinya heterogen (tidak sejenis)".

Dalam penarikan sampel peneliti menggunakan $40 \%$ dari jumlah populasinya. Setelah dilakukan penarikan sampel menggunakan Proportional Random Sampling jumlah sampel yang di peroleh sejumlah 74 responden. Proportional Random Sampling di gunakan oleh peneliti untuk mengambil sampel yang mampu mewakili dalam setiap kelasnya di mana jumlah siswa setiap kelasnya tidak sama. Analisis data dalam penelitian ini menggunakan: (1) Uji prasyarat normalitas analisis ini digunakan untuk mengetahui data harus berdistribusi normal, (2) Regresi linier sederhana analisis ini di gunakan untuk mengetahui hubungan antara variabel motivasi belajar terhadap hasil belajar ekonomi, dan lingkungan teman sebaya terhadap hasil belajar ekonomi, (3) Regresi linier berganda analisis ini digunakan untuk mengetahui hubungan antara semua variabel bebas terhadap variabel terikat, dan (4) Uji hipotesis yang meliputi (uji t dan uji f). Uji t di gunakan untuk mengetahui variabel bebas secara parsial yaitu motivasi belajar terhadap hasil belajar ekonomi dan lingkungan teman sebaya terhadap hasil belajar. Sedangkan uji f di gunakan untuk mengetahui semua variabel bebas terhadap variabel terikat secara bersama-sama atau secara simultan

\section{HASIL DAN PEMBAHASAN}

Berdasarkan gambar 1 di bawah ini, titik-titik variabel motivasi belajar ekonomi, lingkungan teman sebaya dan hasil belajar mata pelajaran ekonomi berada merapat di sekitar garis diagonal sehingga data dikatakan normal dan dapat digunakan untuk penelitian.

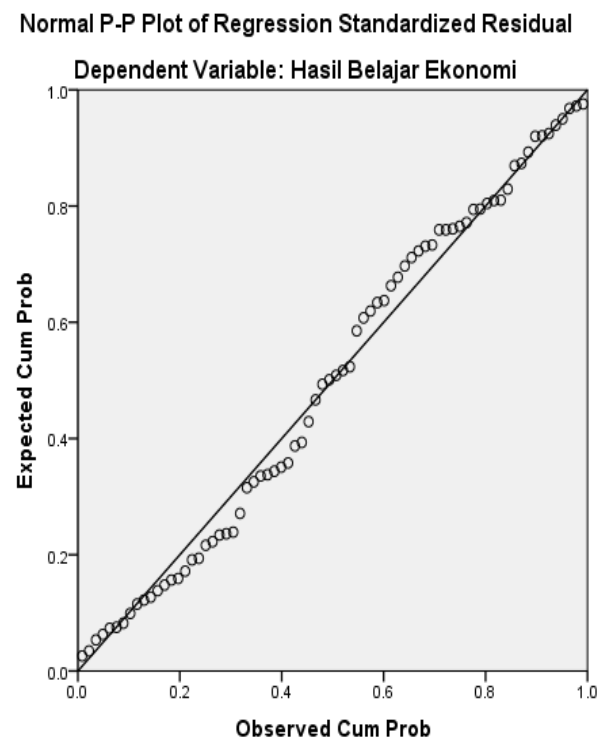

Gambar 1. Uji Normalitas 
Tabel 1. Hasil Analisis Regresi Linier Sederhana Motivasi Belajar Ekonomi $\left(X_{1}\right)$ terhadap Hasil Belajar Mata Pelajaran Ekonomi (Y)

\begin{tabular}{|c|c|c|c|c|c|c|}
\hline & \multirow[b]{2}{*}{ Model } & \multicolumn{2}{|c|}{$\begin{array}{c}\text { Unstandardized } \\
\text { Coefficients }\end{array}$} & \multirow{2}{*}{$\begin{array}{c}\text { Standardized } \\
\text { Coefficients }\end{array}$} & \multirow[b]{2}{*}{$\mathrm{T}$} & \multirow[b]{2}{*}{ Sig. } \\
\hline & & $B$ & Std. Error & & & \\
\hline \multirow[t]{2}{*}{1} & (Constant) & 45,918 & 16,690 & & 2,751 & 0,008 \\
\hline & $\begin{array}{l}\text { Motivasi } \\
\text { Belajar } \\
\text { Ekonomi }\end{array}$ & 1,873 & 0,414 & 0,470 & 4,521 & 0,000 \\
\hline
\end{tabular}

Berdasarkan data pada tabel 1 diperoleh hasil $\hat{Y}=\alpha+b X$ (Riduwan, 2010:145) yaitu: $\hat{Y}=$ $45,918+1,873 \mathrm{X}$, maka jika variabel motivasi belajar ekonomi berniai 0 (nol) maka nilai variabel hasil belajar ekonomi sebesar 45,918 , dan setiap penambahan satu nilai pada variabel $\mathrm{X}_{1}$ maka akan memberikan kenaikan skor sebesar 1,873.

Tabel 2. Koefisien Determinasi Motivasi Belajar Ekonomi $\left(X_{1}\right)$ terhadap Hasil Belajar Mata Pelajaran Ekonomi (Y)

\begin{tabular}{ccccc}
\hline Model & $\mathrm{R}$ & R Square & $\begin{array}{c}\text { Adjusted } \mathrm{R} \\
\text { Square }\end{array}$ & $\begin{array}{c}\text { Std. Error of the } \\
\text { Estimate }\end{array}$ \\
\hline 1 &, $470^{\mathrm{a}}$ &, 221 &, 210 & 19,53204 \\
\hline
\end{tabular}

a. Predictors: (Constant), Motivasi Belajar Ekonomi

Berdasarkan pada tabel 2, diperoleh hasil bahwa angka $\mathrm{R}$ yang didapat sebesar 0,470 , artinya korelasi antara variabel motivasi belajar ekonomi terhadap hasil belajar ekonomi sebesar 0,470 . Dan nilai $\mathrm{R}^{2}$ sebesar 0,221 artinya persentase sumbangan pengaruh motivasi belajar ekonomi terhadap hasil belajar ekonomi sebesar $22,1 \%$ dalam penelitian ini. . Sisanya $77,9 \%$ dipengaruhi oleh faktor internal lain yang tidak di teliti yaitu intelegensi, perhatian, minat, bakat kematangan serta kesiapan.

Tabel 3. Hasil Analisis Regresi Linier Sederhana Lingkungan Teman Sebaya $\left(X_{2}\right)$ terhadap Hasil Belajar Mata Pelajaran Ekonomi (Y)

\begin{tabular}{llllll}
\hline \multicolumn{5}{c}{ Model } & \multicolumn{2}{l}{$\begin{array}{l}\text { Unstandardized } \\
\text { Coefficients }\end{array}$} & $\begin{array}{l}\text { Standardized } \\
\text { Coefficients }\end{array}$ & \\
\cline { 2 - 4 } & $\mathrm{B}$ & Std. Error & Beta & T & Sig. \\
\hline $1 \quad \begin{array}{l}\text { (Constant) } \\
\text { Lingkungan } \\
\quad \text { Teman Sebaya }\end{array}$ & 39,112 & 19,134 & & 2,044 &, 045 \\
& 1,747 &, 407 &, 452 & 4,294 &, 000
\end{tabular}

a. Dependent Variable: Hasil Belajar Ekonomi

Berdasarkan data pada tabel 3 diperoleh hasil $\hat{Y}=\alpha+b X$ (Riduwan, 2010:145) yaitu: $\hat{Y}=$ $39,112+1,747 \mathrm{X}$, maka jika variabel lingkungan teman sebaya berniai 0 (nol) maka nilai variabel hasil belajar ekonomi sebesar 39,112, dan setiap penambahan satu nilai pada variabel $\mathrm{X}_{2}$ maka akan memberikan kenaikan skor sebesar 1,747. 
Tabel 4. Koefisien Determinasi Teman Sebaya $\left(\mathrm{X}_{2}\right)$ terhadap Hasil Belajar Mata Pelajaran Ekonomi $(\mathrm{Y})$

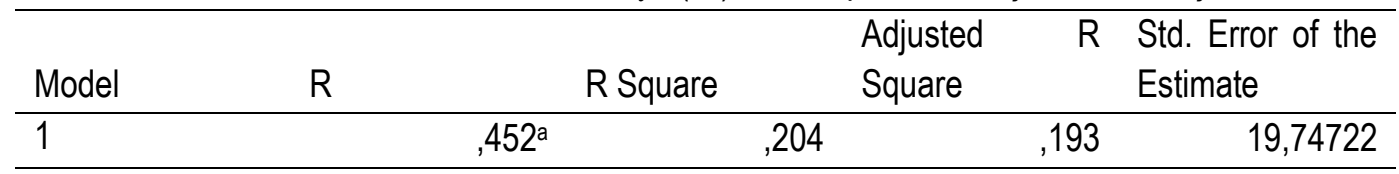

a. Predictors: (Constant), Lingkungan Teman Sebaya

Berdasarkan pada tabel 4, diperoleh hasil bahwa angka $\mathrm{R}$ yang didapat sebesar 0,452 , artinya korelasi antara variabel lingkungan teman sebaya terhadap hasil belajar ekonomi sebesar 0,452. Dan nilai $\mathrm{R}^{2}$ sebesar 0,204 artinya persentase sumbangan pengaruh lingkungan teman sebaya terhadap hasil belajar ekonomi sebesar 20,4\% dalam penelitian ini. Sisanya 79,6\% dipengaruhi oleh faktor eksternal lain yang tidak di teliti yaitu : relasi siswa, siswa di sekolah teman bergaul pada masyarakat.

Dapat dilihat pada tabel 5 menunjukkan bahwa tingkat signifikansi variabel motivasi belajar ekonomi sebesar $0,000<0,05$ maka $h_{o}$ ditolak dan $h_{a}$ diterima, sehingga berdasarkan pengujian hipotesis menunjukkan bahwa terdapat pengaruh signifikansi antara motivasi belajar ekonomi $\left(\mathrm{X}_{1}\right)$ terhadap hasil belajar ekonomi (Y). Nilai variabel lingkungan teman sebaya sebesar $0,000<0,05$ maka $h_{o}$ ditolak dan $h_{a}$ diterima, sehingga berdasarkan pengujian hipotesis menunjukkan bahwa terdapat pengaruh signifikansi antara lingkungan teman sebaya $\left(\mathrm{X}_{2}\right)$ terhadap hasil belajar ekonomi (Y). Adapun hasil analisis regresi linear berganda sebagai berikut:

Tabel 5 Hasil Analisis Regresi Berganda $X_{1}$ dan $X_{2}$ terhadap $Y$

\begin{tabular}{|c|c|c|c|c|c|c|}
\hline \multirow[b]{2}{*}{ Model } & \multicolumn{2}{|c|}{$\begin{array}{l}\text { Unstandardized } \\
\text { Coefficients }\end{array}$} & $\begin{array}{l}\text { Standardized } \\
\text { Coefficients }\end{array}$ & \multirow[b]{2}{*}{$\mathrm{T}$} & \multirow[b]{2}{*}{ Sig. } & \\
\hline & B & Std. Error & Beta & & & \\
\hline $1 \begin{array}{l}\text { (Constant) } \\
\text { Motivasi }\end{array}$ & 16,324 & 19,959 & & ,818 & & , 416 \\
\hline $\begin{array}{l}\text { Belajar } \\
\text { Ekonomi } \\
\text { Lingkungan }\end{array}$ & 1,302 & ,460 & ,327 & 2,832 & & ,006 \\
\hline $\begin{array}{l}\text { Teman } \\
\text { Sebaya }\end{array}$ & 1,122 & ,447 & ,290 & 2,511 & & ,014 \\
\hline
\end{tabular}

Berdasarkan data pada tabel 6 diperoleh hasil bahwa $\hat{Y}=\alpha+b_{1} X_{1}+b_{2} X_{2}$ (Riduwan, 2010, hal.152) yaitu $\hat{\mathrm{Y}}=16,324+1,302 \mathrm{X}_{1}+1,122 \mathrm{X}_{2}$, maka jika variabel independent (motivasi belajar ekonomi dan lingkungan teman sebaya) sebesar 0 (nol), maka nilai variabel dependent (hasil belajar ekonomi) sebesar 16.324. Dan setiap penambahan satu satuan variabel $\mathrm{X}_{1}$ dengan asumsi variabel lain $\left(\mathrm{X}_{2}\right)$ konstan maka hal ini akan berpengaruh peningkatan besarnya $\mathrm{Y}$ sebesar 1,302. Dan setiap penambahan satu satuan variabel $\mathrm{X}_{2}$ dengan asumsi variabel lain $\left(\mathrm{X}_{1}\right)$ konstan maka hal ini akan berpengaruh peningkatan besarnya $\mathrm{Y}$ sebesar 1,122.

Tabel 7. Koefisien Determinasi $X_{1}$ dan $X_{2}$ terhadap $Y$

\begin{tabular}{|c|c|c|c|c|c|}
\hline Model & $\mathrm{R}$ & & R Square & Adjusted R Square & $\begin{array}{l}\text { Std. Error of the } \\
\text { Estimate }\end{array}$ \\
\hline$\overline{1}$ & &, $534^{a}$ & ,285 & ,265 & 18,84990 \\
\hline
\end{tabular}

a. Predictors: (Constant), Lingkungan Teman Sebaya, Motivasi Belajar Ekonomi 
Berdasarkan data pada tabel 7, diperoleh hasil bahwa angka $\mathrm{R}$ yang didapat sebesar 0,534 , artinya korelasi antara variabel motivasi belajar ekonomi dan lingkungan teman sebaya terhadap hasil belajar ekonomi sebesar 0,534 . Dan nilai $\mathrm{R}^{2}$ sebesar 0,285 artinya persentase sumbangan pengaruh motivasi belajar ekonomi dan lingkungan teman sebaya terhadap hasil belajar ekonomi sebesar 28,5\%, sedangkan sisanya sebesar 71,5\% dipengaruhi oleh variabel lain yang tidak diteliti dalam penelitian ini. Variabel lain yang mungkin mempengaruhi hasil belajar ekonomi siswa yaitu : intelegensi, perhatian, minat, kematangan, kesiapan dan relasi siswa.

Adapun hasil uji hipotesis uji F sebagai berikut:

Tabel 8. Hasil Uji Simultan (F) Motivasi Belajar Ekonomi dan Lingkungan Teman Sebaya Terhadap Hasil Belajar Mata Pelajaran Ekonomi

\begin{tabular}{clccccc}
\hline & Model & Sum of Squares & Df & Mean Square & $F$ & Sig. \\
\hline 1 & Regression & 10038,593 & 2 & 5019,297 & 14,126 &, $000^{\mathrm{b}}$ \\
& Residual & 25227,623 & 71 & 355,319 & & \\
& Total & 35266,216 & 73 & & & \\
\hline
\end{tabular}

a. Dependent Variable: Hasil Belajar Ekonomi

b. Predictors: (Constant), Lingkungan Teman Sebaya, Motivasi Belajar Ekonomi

Berdasarkan tabel 8, menunjukkan bahwa tingkat signifikansi variabel motivasi belajar ekonomi dan lingkungan teman sebaya sebesar $0,000<0,05$ maka $h_{o}$ ditolak dan $h_{a}$ diterima. Dengan demikian dapat disimpulkan bahwa secara simultan trdapat pengaruh signifikan antara motivasi belajar ekonomi $\left(\mathrm{X}_{1}\right)$ dan lingkungan teman sebaya $\left(\mathrm{X}_{2}\right)$ terhadap hasil belajar mata pelajaran ekonomi(Y).

Hasil penelitian ini mendukung teori menurut Furqon, K.A (2016, hal.2) "dalam proses belajar mengajar motivasi sangat besar peranannya terhadap hasil belajar. karena dengan adanya motivasi dapat menumbuhkan minat belajar siswa. Bagi siswa yang memiliki motivasi yang kuat akan mempunyai keinginan untuk melaksanakan kegiatan belajar mengajar". Penelitian ini mendukung teori menurut Sani (2013, hal. 49) Peserta didik tidak akan mencapai keberhasilan dalam hasil belajarnya tanpa adanya motivasi belajar.

Hasil penelitian ini mendukung penelitian terdahulu yang dilakukan oleh Dwi Setyani Damayanti (2015) 1 "Pengaruh Motivasi Belajar Dan Lingkungan Keluarga Trhadap Hasil Belajar Matematika Siswa Kelas Vlll-A".Variabel penelitiannyadalah motivasi belajar sebagai variabel bebas $\left(\mathrm{X}_{1}\right)$ dan hasil belajar sebagai variabel terikat $(\mathrm{Y})$. Tampak bahwa hasil dari uji t motivasi belajar diperoleh $(-2,437)$ dengan nilai sign. $0,020(0,020 \leq 0,05)$, maka Ho ditolak dan Ha diterima. Yang artinya motivasi belajar siswa terhadap hasil belajar matematika siswa kelas VIII-A SMP Negeri 2 Tanggulangin dapat diterima secara signifikan. Penelitian ini mendukung penelitian Mut'ah Mutmainah (2014), yang berjudul Pengaruh Motivasi Belajar Terhadap Hasil Belajar Siswa Pada Bidang Studi Sejarah Kebudayaan Islam (SKI) di MTS'N 19 Jakarta. Variabel penelitiannya adalah motivasi belajar sebagai variabel bebas (X) dan hasil belajar sebagai variabel terikat (Y). Bahwa motivasi belajar mempunyai pengaruh yang signifikan terhadap hasil belajar siswa pada bidang studi Sejarah Kebudayaan Islam (SKI). Hal ini ditunjukkan melalui koefisien korelasi sebesar 0,4231. Penelitian ini mendukung penelitian menurut Erma Yuli (2016) dengan judul "Pengaruh Motivasi Belajar Dan Minat Baca Terhadap Hasil Belajar Ekonomi Siswa Kelas XI IPS Semester Ganjil SMA Negeri 15 Bandar Lampung Tahun Ajaran 2015/2015. Variabel penelitiannya adalah motivasi belajar sebagai variabel bebas $\left(\mathrm{X}_{1}\right)$ dan hasil belajar sebagai variabel terikat $(\mathrm{Y})$. Yang menyatakan bahwa terdapat pengaruh yang positif dan signifikan antara motivasi belajar terhadap hasil belajar ekonomi siswa kelas XI IPS semester ganjil SMA Negeri 15 Bandar 
Lampung Tahun Ajaran 2015/2016. Dengan kata lain, semakin tinggi motivasi belajar siswa, maka semakin tinggi pula hasil belajarnya.

Berdasarkan ketiga penelitian terdahulu dan penelitian yang dilakukan peneliti ini dapat disimpulkan terdapat pengaruh signifikan antara motivasi belajar terhadap hasil belajar mata pelajaran ekonomi.

Hasil penelitian ini mendukung teori menurut Julianty (2014, hal. 2-3)Teman sebaya dapat memberikan dampak positif maupun negatif. Teman sebaya yang baik dapat memberikan pengaruh yang positif, dimana teman sebaya dapat memberikan dorongan untuk giat belajar agar mencapai hasil belajar yang baik dan mampu bersaing secara sehat dalam kegiatan belajar. Penelitian ini mendukung teori menurut (Maheni, 2017) Teman sebaya biasanya memberikan dorongandorongan sekaligus suasana membangun apabila berada di dalam kelas atau di luar kelas, memiliki usia dan tingkat kematangan yang relatif sama, sehingga terjalin komunikasi yang dialogis.

Hasil penelitian ini mendukung penelitian terdahulu yang dilakukan oleh Retno Singga Dewi 2015 yang berjudul "Pengaruh Disiplin Belajar Dan Lingkungan Teman Sebaya Terhadap Hasil Belajar Siswa Pada Mata Pelajaran Ekonomi Kelas XI IPS Di SMA Negeri 14 Semarang”. Variabel penelitiannya adalah lingkungan teman sebaya sebagai variabel bebas $\left(\mathrm{X}_{2}\right)$ dan hasil belajar sebagai variabel terikat $(\mathrm{Y})$. yang menunjukkan dari hasil penelitiannya menunjukkan bahwa terdapat pengaruh secara parsial lingkungan teman sebaya terhadap hasil belajar siswa pada mata pelajaran ekonomi kelas X1 IPS di SMA Negeri 14 Semarang tahun ajaran 2014/2015 sebesar 18,8\%.

Berdasarkan dari penelitian terdahulu dan penelitian yang dilakukan peneliti ini dapat disimpulkan terdapat pengaruh signifikan lingkungan teman sebaya terhadap hasil belajar mata pelajaran ekonomi. Hasil penelitian ini mendukung teori Julianty (2014, hal. 2-3), bahwa "hasil belajar dipengaruhi oleh faktor internal dan eksternal. Faktor internal yang dapat mempengaruhi hasil belajar meliputi : kondisi fisik seseorang, intelegensi, perhatian, minat, bakat, motivasi, kematangan dan kesiapan. Sedangkan faktor eksternalnya meliputi : relasi siswa, siswa di sekolah, teman bergaul pada masyarakat dan teman sebaya.

Hasil penelitian ini mendukung penelitian terdahulu yang dilakukan oleh Septiana Rahayu (2015) yang berjudul "Pengaruh Lingkungan Teman Sebaya Dan Motivasi Belajar Terhadap Hasil Belajar Ekonomi Siswa Kelas X IPS SMA Negeri 1 Sewon Tahun Ajaran 2016/2017”. Hasil penelitiannya menunjukkan: 1) Terdapat pengaruh signifikan lingkungan teman sebaya terhadap hasil belajar siswa dengan nilai t hitung 5,732 dan nilai signifikansi 0,000. 2) Terdapat pengaruh signifikan motivasi belajar terhadap hasil belajar siswa dengan nilai t hitung 4,896 dan nilai signifikansi 0,000. 3) Terdapat pengaruh signifikan lingkungan teman sebaya dan motivasi belajar terhadap hasil belajar siswa dengan nilai Fhitung sebesar 43,378 dan nilai signifikansi F sebesar 0,000. Besarnya koefisien determinasi (R2) sebesar 0,457 atau 45,7\%. Hasil ini mengindikasikan bahwa hasil belajar dapat dijelaskan oleh variabel lingkungan teman sebaya dan motivasi belajar sebesar 45,7\%, sedangkan sisanya 54,3\% dijelaskan oleh variabel lain yang tidak diteliti.

Berdasarkan dari penelitian terdahulu dan penelitian yang dilakukan peneliti ini dapat disimpulkan terdapat pengaruh signifikan motivasi belajar ekonomi dan lingkungan teman sebaya terhadap hasil belajar mata pelajaran ekonomi.

\section{SIMPULAN}

Berdasarkan rumusan masalah dalam penelitian ini maka dapat disimpulkan sebagai berikut: Secara parsial terdapat pengaruh yang signifikan motivasi belajar ekonomi dan lingkungan teman sebaya terhadap hasil belajar mata pelajaran ekonomi Siswa kelas X SMA Negeri 1 Kampak Tahun Pelajaran 2017/2018. Secara simultan terdapat pengaruh signifikan antara motivasi belajar 
ekonomi $\left(\mathrm{X}_{1}\right)$ dan lingkungan teman sebaya $\left(\mathrm{X}_{2}\right)$ terhadap hasil belajar mata pelajaran ekonomi $(\mathrm{Y})$ Siswa kelas X SMA Negeri 1 Kampak Tahun Pelajaran 2017/2018.

\section{DAFTAR PUSTAKA}

Arikunto, Suharsimi. (2002). Prosedur Penelitian Suatu Pendekatan Praktek.Jakarta: PT Rineka Cipta

Damayanti, D. S. (2015). Pengaruh Motivasi Belajar Dan Lingkungan Keluarga Terhadap Hasil Belajar Matematika Siswa Kelas VIII-A. Influence OfMotivation To Learn And Family Environment Of Learning Math Class Viii-A. (Vol 3(2), pp 101-112).

Dewi, R. S. (2015). Pengaruh Disiplin Belajar Dan Lingkungan Teman Sebaya Terhadap Hasil Belajar Siswa Pada Mata Pelajaran Ekonomi KELAS XI IPS DI SMA Negeri 14 Semarang.

Djaali H. (2009). Psikologi Pendidikan. Jakarta: PT Bumi Aksara

Furqon, K. A. (2016). Pengaruh Kedisiplinan Dan Motivasi Belajar Siswa Terhadap Hasil Belajar Mata Pelajaran Ips Kelas X, XI Dan XII Teknik Komputer Jaringan Di Smk Hayam Wuruk Singosari Malang.

Habsari Sri. (2005). Bimbingan dan Konseling SMA Untuk Kelas X1

Julianty, R. (2014). Pengaruh Teman Sebaya Terhadap Hasil Belajar Pengolahan Dan Penyajian Makanan Indonesia Pada Siswa SMK, 1-8.

Maheni, N. P. K. (2017). Pengaruh Gaya Belajar Dan Lingkungan Teman Sebaya Terhadap Hasil Belajar Mahasiswa Di Jurusan Pendidikan Ekonomi Universitas Pendidikan Ganesha, Vol: 10 No.

Mutmainah, M. (2014). Pengaruh Motivasi Belajar Terhadap Hasil Belajar Siswa Pada Bidang Studi Sejarah Keudayaan Islam (SKI) Di MTS N 19 Jakarta.

Rahayu, S. (2017). Pengaruh Lingkungan Teman Sebaya Dan Motivasi Belajar Terhadap Hasil Belajar Ekonomi Siswa Kelas X IIS SMA Negeri 1 Sewon Tahun Ajaran 2016/2017.

Riduwan.(2010). Metode \& Teknik Menyusun Tesis.Bandung: Alfabeta

Sani A. Ridwan. (2013). Inovasi Pembelajaran.Jakarta: PT Bumi Aksara

Wekke S. Ismail. (2016). Pembelajaran Bahasa Arab di Madrasah.Yogyakarta: Depublish

Yuli, E. (2016). Pengaruh Motivasi Belajar Dan Minat Baca Terhadap Hasil Belajar Ekonomi Siswa Kelas XI IPS Semester Ganjil SMA Negeri 15 Bandar Lampung Tahun Ajaran 2015/2016, 2016. 